\title{
Physicochemical Assessment of Rain Water of Karachi, Pakistan
}

\author{
Mahwish Chughtai $^{a}$, Sana Mustafa ${ }^{\mathrm{a}, b} *$, Majid Mumtaz ${ }^{a}$ \\ ${ }^{a}$ Department of Chemistry, University of Karachi-75270, Pakistan \\ ${ }^{b}$ Department of Chemistry, Federal Urdu University of Arts, Science \& Technology, Gulshan-e-Iqbal Campus, Karachi- \\ 75300, Pakistan
}

\begin{abstract}
Local Precipitation (Rain) is a good source of surface water and could be a safe source of drinking water if it is free from contaminants. Many Asian countries do not have access to safe drinking water; therefore, they have no alternative but to use water from contaminated sources that poses a health hazard. In the present study, thirty three rain water samples were collected from Karachi, Pakistan during monsoon season of year 2007. The pH, electrical conductivity (EC), total dissolved solids (TDS), dissolved oxygen (DO) and hardness were immediately monitored after sample collections and possible sources of $\mathrm{NH}_{4}, \mathrm{Na}, \mathrm{K}, \mathrm{Mg}, \mathrm{Ca}, \mathrm{F}^{-}, \mathrm{Cl}^{-}, \mathrm{NO}_{3}{ }^{-}, \mathrm{CO}_{3}^{-2}$ and $\mathrm{SO}_{4}{ }^{-2}$ concentrations in rain water of Karachi city, Sindh, Pakistan were analyzed in order to distinguish safe source of drinking water. All samples were completely free from fluoride contamination while the concentration of chloride and sulfate was in range of 15.11-125 mg/l and 10.02$72.02 \mathrm{mg} / \mathrm{l}$ indicate their presence from air pollution. Moreover, the study showed that the rain water can be harvested to extend potable and non-potable water supplies in this city.
\end{abstract}

Keywords: rain water, air pollution, physicochemical parameters, Karachi, drinking water

\section{Introduction}

Pakistan is located between $24^{\circ}$ and $37^{\circ} \mathrm{N}$ and $61^{\circ}$ and $75^{\circ} \mathrm{E}$. Most part of the country receives low rainfall and high solar radiation. Northern areas receive more than $500 \mathrm{~mm}$ rain fall annually. The annual rain fall in Sindh is $60 \%$ [1]. Most of the rangelands of Pakistan are in arid and semi-arid zones characterized by low precipitation and extremes of temperature and low humidity [2]. Karachi is the metropolitan city of Pakistan and it is also situated in Sindh. Climate of Karachi is arid with annual rainfall of $250 \mathrm{~mm}$ occur in monsoon season from July to August [3].

Pollution is increasing due to anthropogenic and agricultural activities, fast urbanization, rapid industrial development, poor sanitation system and unhygienic practices by general public. Chemical composition of rain water is influenced by the contents of the atmosphere through which it falls. Precipitation is also a

${ }^{*}$ Corresponding author. Tel.: 92-21-345295733

Fax: 92-42-36298302; E-mail: sanachemana@yahoo.com

(C) 2014 International Association for Sharing Knowledge and Sustainability.

DOI: $10.5383 /$ swes.06.01.0005 path way for removing gases and particles from the atmosphere. During removal process oxides of sulphur and nitrogen incorporated into rain water which are chemically converted into sulfuric and nitric acid $[4,5]$. The scavenging of the atmospheric pollutant affects the chemical composition and $\mathrm{pH}$ of rain water. The acidity value depends upon the neutralization produced by certain rain water components such as $\mathrm{NH}_{3}, \mathrm{CaCO}_{3}$ and hydroxide. Low $\mathrm{pH}$ rain and atmospheric aerosols are considered to be typical environmental pollution affecting human health, acidification of lake and soil, deterioration of monuments and natural equilibrium [6, 7].

The quality of rain water depends upon the variation in rain water composition. It varies form place to place and season to season due to climate, topography, location of sampling site and natural and anthropogenic sources etc. This study was aid to understand the effect of natural and anthropogenic effect on the quality of rain water. In order to estimate the effect of pollution in air we 
analyzed rain water samples collected from eighteen towns of Karachi, Pakistan.

\section{Materials and Methods}

\subsection{Sample Collection}

Rain water samples were collected from eighteen different towns of Karachi, Pakistan in the Monsoon season of 2007 in clean buckets.

\subsection{Sample Storage}

Water samples were transferred to the polypropylene bottles that were pre rinsed with deionized water. A total of thirty three samples were collected and their $\mathrm{pH}, \mathrm{EC}, \mathrm{DO}$, TDS and hardness were measured immediately after sample collection. Each sample was filtered through $0.25 \mu \mathrm{m}$ filter paper (Millipore, USA) and divided into two portions. One part was stored under refrigeration for anion analysis and other portion was acidified with $\mathrm{HNO}_{3}$ (Merck) for cation analysis.

\subsection{Instrumentation}

The major cations were measured by Perkin-Elmer atomic absorption spectrophotometer (AAnalyst 700). Anions were analyzed by ion chromatography (Metrohm 761 Compact IC with suppressed module, equipped with an anion-separator column (Dual 2). pH, EC, DO and $\mathrm{NH}_{4}$ was analyzed by multi parameter ion analyzer (HANNA Instrument).

\section{Results and Discussion}

Rain water is one of a major source of drinking water on this planet. It collects in rivers, lakes, streams, dams, etc. It is also seep through the ground and recharges the ground water table that supplies drinking water to wells and boreholes.

The research is conducted to monitor the quality of rain water in Karachi, Pakistan in order to find the extent of air pollution and to find considerable scope for the collection and storage of rain water when it falls, in spite of its huge losses occur due to evaporation, transpiration and contamination by natural and anthropogenic pollutions.

\section{1. $\mathrm{pH}$}

The $\mathrm{pH}$ value of rain water samples ranged between 5.91-7.68 the rain water sample obtained from sadder has a slightly acidic $\mathrm{pH}$ where as Korangi Industrial Area is slightly basic. A significant change is not observed in rain water samples. The range of $\mathrm{pH}$ in rain water is in permissible limit of WHO (World Health Organization) standard of water use for drinking purpose.

\subsection{Electrical Conductivity (EC)}

The value of EC ranged from $0.03-0.17 \mathrm{~m} . \mathrm{S}$. The rain water samples collected from North Nazimabad and PCSIR has a lowest EC value where as Korangi industrial area has highest EC value in rain water samples.

\subsection{Total Dissolved Solids (TDS)}

The highest value of TDS was found in Korangi industrial area i.e. $127 \mathrm{mg} / \mathrm{l}$ and lowest value was found in North Nazimabad town, Sakhi Hassan sample i.e. 26 $\mathrm{mg} / \mathrm{l}$.

\subsection{Dissolved Oxygen (DO)}

The value of dissolved oxygen ranged from 6.9-7.8 mg/l. Lowest value was obtained in Orangi town sample and highest value was obtained in PCSIR and Liaquatabad samples.

\subsection{Hardness}

Lowest value of hardness was obtained in Gulshan-eHadid sample i.e. $19.80 \mathrm{mg} / \mathrm{l}$ and highest in Golimar sample i.e. $73 \mathrm{mg} / \mathrm{l}$.

\subsection{Ammonium}

The value of $\mathrm{NH}_{4}$ ranged in between 10.94 to 154.40 $\mathrm{mg} / \mathrm{l}$. The lowest value was found in Karachi University sample where as highest value was found in North Karachi sample.

\subsection{Sodium}

Highest value was found in Saddar sample i.e. 116.20 $\mathrm{mg} / \mathrm{l}$ where as lowest value was found in Garden West sample with concentration of $5.515 \mathrm{mg} / \mathrm{l}$.

\subsection{Potassium}

Highest value was found in North Karachi sample and lowest value was found in Khokrapar sample.

\subsection{Magnesium}

The highest concentration of $\mathrm{Mg}$ was obtained is 121.03 $\mathrm{mg} / \mathrm{l}$ which was found in Malir Hault sample and lowest value was obtained in Liaquatabad sample i.e. 11.02 $\mathrm{mg} / \mathrm{l}$.

\subsection{Calcium}

The concentration of calcium in rain water sample is ranged from 12.00 to $134.30 \mathrm{mg} / \mathrm{l}$. The highest value of calcium was found in Malir Hault sample of Malir town and the lowest concentration of calcium was obtained in sample collected from Cantonment area of Defence.

\subsection{Chloride}


The value ranged between 15.11-125 mg/l. Lowest value was obtained in PCSIR while highest value was obtained in Korangi industrial area.

\subsection{Fluoride}

All samples were completely free from fluoride.

\subsection{Nitrate}

Lowest value was found in Gulistan-e-Jauhar sample i.e. $9.82 \mathrm{mg} / \mathrm{l}$ and highest in Saddar sample i.e. $72.0 \mathrm{mg} / 1$.

\subsection{Carbonate}

The concentration of carbonate ranged between 13.23$62.03 \mathrm{mg} / \mathrm{l}$. Lowest value was obtained in New Karachi while highest value was obtained in Khokrapar sample.

\subsection{Sulfate}

The value ranged between 10.02-72.02 mg/l. Lowest value was obtained in New Karachi while highest value was obtained in Khokrapar sample.

All the estimated physicochemical parameters of the investigated rain water samples are within the standard limits of drinking water given by World Health Organization.

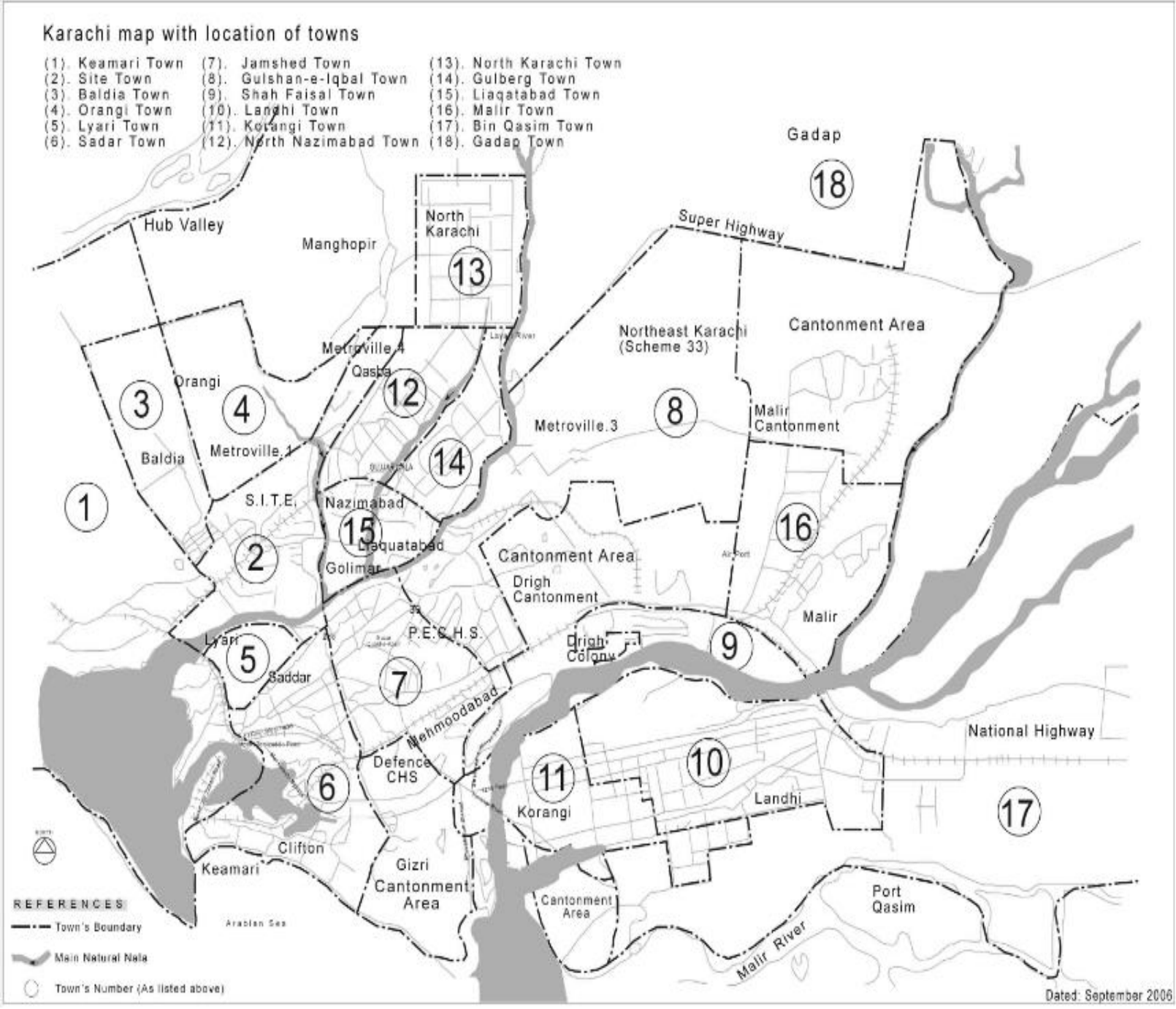

Fig. 1. Map of Karachi City, Pakistan indicating sampling locations 


\begin{tabular}{|c|c|c|c|c|c|c|c|c|c|c|c|c|c|c|c|c|}
\hline \multirow{2}{*}{$\begin{array}{c}\text { S.No } \\
\\
\\
\\
1\end{array}$} & \multicolumn{2}{|c|}{ Areas/Parameters } & \multirow{2}{*}{$\begin{array}{c}\mathrm{pH} \\
\\
\\
7.1\end{array}$} & \multirow{2}{*}{$\begin{array}{c}\text { E.C } \\
(\mathrm{m} . \mathrm{S}) \\
0.07\end{array}$} & \multirow{2}{*}{$\begin{array}{c}\text { TDS } \\
(\mathrm{mg} / \mathrm{l}) \\
\\
99.08\end{array}$} & \multirow{2}{*}{$\begin{array}{c}\text { D.O } \\
(\mathrm{mg} / \mathrm{l}) \\
\\
7.1\end{array}$} & \multirow{3}{*}{$\begin{array}{c}\text { Hard- } \\
\text { ness } \\
(\mathrm{mg} / \mathrm{l})\end{array}$} & \multirow{3}{*}{$\begin{array}{c}\mathrm{NH}_{4} \\
(\mathrm{mg} / \mathrm{l})\end{array}$} & \multirow{2}{*}{$\begin{array}{c}\mathrm{Na} \\
(\mathrm{mg} / \mathrm{l}) \\
\\
95.34\end{array}$} & \multirow{3}{*}{$\begin{array}{c}\mathrm{K} \\
(\mathrm{mg} / \mathrm{l}) \\
6.32\end{array}$} & \multirow{3}{*}{$\begin{array}{c}\mathrm{Mg} \\
(\mathrm{mg} / \mathrm{l})\end{array}$} & \multirow{3}{*}{$\begin{array}{c}\mathrm{Ca} \\
(\mathrm{mg} / \mathrm{l}) \\
\\
95.32\end{array}$} & \multirow{3}{*}{$\begin{array}{c}\mathrm{Cl}^{-} \\
(\mathrm{mg} / \mathrm{l}) \\
\\
75.82\end{array}$} & \multirow{3}{*}{$\begin{array}{c}\mathrm{NO}_{3}^{-} \\
(\mathrm{mg} / \mathrm{l}) \\
\\
59.32\end{array}$} & \multirow{2}{*}{$\begin{array}{l}\mathrm{CO}_{3}^{-2} \\
(\mathrm{mg} / \mathrm{l}) \\
\\
59.32\end{array}$} & \multirow{3}{*}{$\begin{array}{l}\mathrm{SO}_{4}^{-2} \\
(\mathrm{mg} / \mathrm{l})\end{array}$} \\
\hline & Keamari & Keamari & & & & & & & & & & & & & & \\
\hline & Town & SherShah & 7.0 & 0.06 & 95.26 & 7.1 & & & 85.32 & & & & & & 55.96 & \\
\hline \multirow[t]{2}{*}{2} & SITE Town & Pak Colony & 6.5 & 0.10 & 72 & 7.0 & 69 & 52.9 & 85.30 & 5.83 & 25.32 & 22.51 & 85.35 & 42.03 & 32.02 & 19.36 \\
\hline & & Banaras Colony & 6.4 & 0.09 & 73 & 7.1 & 70 & 50.30 & 82.32 & 5.23 & 22.53 & 22.01 & 82.36 & 40.21 & 30.25 & 20.96 \\
\hline \multirow[t]{2}{*}{3} & Baldia & Saeedabad & 6.3 & 0.05 & 60.3 & 7.2 & 62 & 15.15 & 55.92 & 2.58 & 19.02 & 16.52 & 65.11 & 29.15 & 22.39 & 31.01 \\
\hline & Town & Muhajir Camp & 6.3 & 0.05 & 59.32 & 7.2 & 59 & 16.25 & 52.31 & 2.96 & 21.03 & 21.22 & 62.13 & 25.99 & 23.52 & 28.59 \\
\hline 4 & $\begin{array}{l}\text { Orangi } \\
\text { Town }\end{array}$ & Mohammad Nagar & 6.2 & 0.09 & 72 & 6.8 & 59 & 25.98 & 41.02 & 5.8 & 15 & 19 & 50 & 25.02 & 32.56 & 15.20 \\
\hline 5 & Lyari Town & Bihar Colony & 7.32 & 0.12 & 115 & 7.0 & 70 & 46.52 & 99.09 & 6.2 & 52.58 & 92.72 & 102 & 35.31 & 52.15 & 32.25 \\
\hline \multirow[t]{3}{*}{6} & Saddar & Saddar & 5.91 & 0.076 & 60.3 & 7.2 & 57.5 & 56.44 & 116.20 & 7.20 & 36.50 & 89.50 & 112 & 72.0 & 41.84 & 70.40 \\
\hline & Town & Garden West & 6.55 & 0.16 & 112 & 6.9 & 57.90 & 50.10 & 5.515 & 2.50 & 26.32 & 52.36 & 23.70 & 19.02 & 25.06 & 21.42 \\
\hline & & Defence & 6.6 & 0.04 & 69 & 7.3 & 52 & 42.36 & 9.60 & 7.0 & 14 & 12 & 32 & 30.01 & 26.02 & 42.60 \\
\hline 7 & $\begin{array}{c}\text { Jamshed } \\
\text { Town }\end{array}$ & PECHS & 7.12 & 0.13 & 103 & 7.0 & 65 & 65.03 & 26.50 & 6.11 & 29.32 & 49.34 & 25.31 & 28.36 & 49.35 & 32.52 \\
\hline
\end{tabular}


Mahwish Chughtai et. al. / Int. J. of Sustainable Water and Environmental Systems, Vol. 6, No. 1 (2014) 45-51

\begin{tabular}{|c|c|c|c|c|c|c|c|c|c|c|c|c|c|c|c|c|}
\hline \multirow[t]{4}{*}{8} & Gulshan & Karachi University & 6.75 & 0.06 & 50.3 & 7.1 & 40.3 & 10.94 & 50.25 & 2.69 & 47.02 & 83.90 & 43.00 & 17.60 & 52.03 & 28.40 \\
\hline & Town & PCSIR & 6.11 & 0.03 & 27 & 7.8 & 29.42 & 98.25 & 32.05 & 1.99 & 22.30 & 35.20 & 15.11 & 10.02 & 42.05 & 20.02 \\
\hline & & Gulistan-e- Jauhar & 6.38 & 0.15 & 106 & 7.2 & 70 & 68.02 & 25.36 & 6.90 & 14.00 & 32.03 & 19.24 & 9.82 & 32.02 & 20.00 \\
\hline & & Gulshan-e-Iqbal & 6.5 & 0.06 & 70 & 7.2 & 59.20 & 45.02 & 19.40 & 7.25 & 12.00 & 19 & 74 & 42.01 & 22.52 & 13 \\
\hline \multirow[t]{3}{*}{9} & Shah Faisal & Drigh Colony & 6.81 & 0.04 & 38 & 7.6 & 32.70 & 24.25 & 40.25 & 4.00 & 25.30 & 43.00 & 30.60 & 22.03 & 20.01 & 52.03 \\
\hline & & Green Town & 6.86 & 0.08 & 50.3 & 7.3 & 31.5 & 22.62 & 21.16 & 6.71 & 78.40 & 62.50 & 32.30 & 11.25 & 19.25 & 15.40 \\
\hline & & Colony Gate & 6.42 & 0.08 & 64 & 6.7 & 22.30 & 24.75 & 19.26 & 5.02 & 55.02 & 60.23 & 29.32 & 25.26 & 26.32 & 24.11 \\
\hline 10 & $\begin{array}{l}\text { Landhi } \\
\text { Town }\end{array}$ & Dawood Chowrangi & 7.32 & 0.12 & 120 & 7.3 & 69 & 102.5 & 65.92 & 6.32 & 59.21 & 85.32 & 25.29 & 19.52 & 39.25 & 42.39 \\
\hline 11 & $\begin{array}{c}\text { Korangi } \\
\text { Town }\end{array}$ & Korangi Industrial Area & 7.68 & 0.17 & 127 & 7.1 & 65 & 42.02 & 25.4 & 0.601 & 15.00 & 21 & 125 & 72.02 & 18.25 & 65.6 \\
\hline 12 & $\begin{array}{c}\text { North } \\
\text { Nazimabad } \\
\text { Town }\end{array}$ & Sakhi Hassan & 6.07 & 0.03 & 26 & 7.0 & 24.8 & 21.52 & 54.80 & 4.02 & 15.24 & 22.03 & 51 & 21.02 & 30.89 & 13.02 \\
\hline 13 & $\begin{array}{l}\text { New } \\
\text { Karachi } \\
\text { Town }\end{array}$ & New Karachi & 6.03 & 0.09 & 76 & 7.2 & 51 & 154.40 & 52.03 & 7.71 & 26.40 & 25.02 & 47 & 22.03 & 62.03 & 72.02 \\
\hline 14 & $\begin{array}{l}\text { Gulberg } \\
\text { Town }\end{array}$ & Ancholi & 6.52 & 0.05 & 85 & 7.4 & 35 & 65.21 & 85.56 & 6.30 & 21.03 & 52.11 & 39.23 & 31.03 & 21.39 & 19.25 \\
\hline
\end{tabular}


Mahwish Chughtai et. al. / Int. J. of Sustainable Water and Environmental Systems, Vol. 6, No. 1 (2014) 45-51

\begin{tabular}{|c|c|c|c|c|c|c|c|c|c|c|c|c|c|c|c|c|}
\hline \multirow[t]{2}{*}{15} & Liaquatabad & Liaquatabad & 6.04 & 0.04 & 39 & 7.8 & 40.35 & 58.25 & 46.00 & 5.28 & 11.02 & 33.01 & 25.03 & 12.58 & 25.09 & 15.03 \\
\hline & Town & Golimar & 7.39 & 0.11 & 88 & 6.9 & 73 & 40.11 & 11.90 & 5.2 & 21 & 22 & 45 & 20.01 & 58.57 & 19.25 \\
\hline \multirow[t]{5}{*}{16} & Malir Town & Model Colony & 6.87 & 0.08 & 62 & 7.0 & 41.90 & 44.32 & 12.39 & 2.99 & 58.11 & 47.02 & 52.03 & 23.25 & 30.21 & 30.25 \\
\hline & & Malir Hault & 6.29 & 0.09 & 65 & 7.2 & 44 & 82.31 & 20.25 & 2.50 & 121.03 & 134.30 & 49.01 & 32.01 & 32.02 & 21.00 \\
\hline & & Kausar Town & 6.30 & 0.09 & 63 & 6.9 & 44 & 62.02 & 15.02 & 3.89 & 44.25 & 56.85 & 15.21 & 35.02 & 32.25 & 24.02 \\
\hline & & Malir City & 6.70 & 0.08 & 60 & 7.0 & 38 & 58.25 & 14.22 & 6.99 & 61 & 47.25 & 49.99 & 25.82 & 30.25 & 17.02 \\
\hline & & Khokrapar & 6.37 & 0.05 & 67 & 7.2 & 50.70 & 50.02 & 15.0 & 0.39 & 24 & 22 & 16.23 & 47.25 & 13.23 & 10.02 \\
\hline 17 & $\begin{array}{c}\text { Binqasim } \\
\text { Town }\end{array}$ & Gulshan-e -Hadid & 6.34 & 0.05 & 44 & 7.2 & 19.80 & 52.02 & 25.23 & 3.02 & 29.25 & 32.58 & 26.25 & 15.24 & 15.02 & 49.02 \\
\hline \multirow[t]{3}{*}{18} & Gadap & Gadap & 6.92 & 0.04 & 89 & 7.6 & 65 & 85.11 & 55.38 & 5.5 & 45.21 & 62.02 & 25.31 & 25.82 & 45.34 & 22.39 \\
\hline & Town & & & & & & & & & & & & & & & \\
\hline & \multicolumn{2}{|c|}{ WHO Standard } & $6.5-8.5$ & NLL & 500 & NLL & $0-75$ & NLL & 200 & NLL & 50 & 200 & 250 & 45 & NLL & 250 \\
\hline
\end{tabular}

NLL= No limit listed 


\section{Conclusion}

The quality of rain water can be easy used as a tool for the assessment of air pollution. In this study, a good number of samples were collected and their major physicochemical parameters were determined. All the samples meet the quality of WHO drinking water standards and free from considerable pollution. Therefore, we propose from the study that the rain water can be collected and stored for potable and non-potable purposes in Karachi, Pakistan.

\section{Acknowledgment}

We gratefully acknowledge Prof. Dr. Iftikhar Imam Naqvi, Chairman Department of Chemistry, University of Karachi, Pakistan for providing research facilities and Dr. Rashid Ali Khan of PCSIR, Laboratories Complex, Karachi, Pakistan for his valuable suggestions in writing this manuscript.

\section{References}

[1] FAO. Pakistan's experience in rangeland rehabilitation and improvement. Food and Agriculture Organization of the United Nations, 1987: 70 .

[2] Climate data Karachi. Pakistan Meteorological Department, Government of Pakistan. Retrieved September 2010.
[3] Umrani AP, English PR, Younie D. A mathematical modeling approach for sustainable rangeland utilization in Sindh. Modern Agriculture, Pakistan 1996; 7: 4-16.

[4] Suresh T, Ashwani R, Deewan S. Study of chemical species in rain water at Ballia, Uttar Pradesh, India. Indian journal of Radio \& space physics 2006; 35: 35-41.

[5] Khan AR, Kyung-Sok MM, Marwat GA, Riaz M. Potable water quality characteristics of urban areas of Peshawar, Pakistan. Journal of Chemical Society of Pakistan 2005; 27 (3): 239245.

[6] Aohan T, Guoshan Z, Ying W, Yeresun. Chemistry of precipitation and its relation to aerosol in Beijing. Atmospheric Environment 2005; 39(19): 3397-3406.

[7] Omer AA. Study of chemical composition in wet atmospheric precipitation in Eshdiya, Jordan. Atmospheric Environment 2005; 39 (13): 6175-6183. 